\title{
Tenebrio molitor and its gut bacteria growth in polystyrene (PS) presence as the sole source carbon
}

\author{
Paula M. Peña-Pascagaza ${ }^{1}$, Nathalia A. López-Ramírez ${ }^{1}$, Miguel A. Ballen-Segura, ${ }^{1, *}$
}

Edited by

Juan Carlos Salcedo-Reyes

(salcedo.juan@javeriana.edu.co)

1. Universidad Sergio Arboleda,

Calle 74 No. 14-14, Bogotá, Colombia.

*miguel.ballen@usa.edu.co

Received: 26-10-2018

Accepted: 30-08-2019

Published on line: 24-02-2020

Citation: Peña-Pascagaza PM,

López-Ramírez NA, Ballen-Segura MA.

Tenebrio molitor and its gut bacteria

growth in polystyrene (PS) presence as

the sole source carbon,

Universitas Scientiarum, 25 (1): 37-53, 2020.

doi: 10.11144/Javeriana.SC25-1.tmai

Funding:

The funding was made by Universidad Sergio Arboleda

Electronic supplementary material: N.A.

OPEN ACCESS

\begin{abstract}
Although polystyrene (PS) is considered a non-biodegradable material, recent work has shown the degradation capacity of this material by microorganisms, especially those that are part of the natural microbiota of the digestive tract of some invertebrates. The present work sought to evaluate the growth of the larva of the mealworm (Tenebrio molitor) and its bacteria, using PS as the sole source of carbon. In this way it was possible to demonstrate the consumption of PS plates by the larva, found in holes and tunnels in the material, however, nutritionally it is not enough for the larva to gain biomass, notably reducing its size and time survival. Similarly, bacteria isolated from the digestive tract of T. molitor presented the ability to generate biofilms on PS s heets, g enerating c hanges (cracks, holes, etc.) in them, which were observed under scanning electron microscopy (SEM), indicating the possible use of this material as a carbon source for its growth.
\end{abstract}

Keywords: beetle; gut bacteria; polystyrene; Styrofoam; Tenebrio.

\section{Introduction}

Plastic is one of the most used materials in modern human societies. A derivative of oil, plastic has a light weight and is resistant, flexible, and relatively inert. These features make it ideal as a raw material for bags, packaging, construction material, thermal and electrical insulation products, etc. Annually, 250 million tons of plastic are produced in the world and $40 \%$ of which is destined to the production of packaging (Cardoso et al., 2017). However, only $9.5 \%$ is recycled or reused. The remaining reaches landfills and dumps (Zalasiewicz et al., 2016). Most of the massively consumed plastic serves its purpose in a short time and, depending on the complexity of the material, its degradation time can be short or long. This leads to an accumulation of plastic in aquatic systems and soils that negatively impact the biosphere and generate foci of contamination leading to public health issues (Barnes et al., 2009). Polystyrene (PS) is a plastic that, given its versatility and low cost, has been used in a wide range of consumer products, such as insulation materials, food packaging, cutlery and kitchen utensils, among 
others. In Colombia, PS is produced at a capacity of 110000 tons per year and is the third most-produced petroleum-derived plastic, after polyvinyl chloride and propylene polymers (Acoplásticos, 2017). The expanded form of polystyrene is perhaps the most produced PS type thanks to its low density, hygroscopic properties, and innocuousness, making it a sought-after supply for the production of packaging items and construction and insulation materials (Ferrándiz-Mas \& García-Alcocel, 2013). However, these characteristics also make it a highly resistant material to microbial degradation.

Taking into account the complexity of this material and its accumulation in ecosystems, methods of thermal decomposition have been proposed. However, these techniques, besides being expensive, generate large quantities of dioxins and aromatic compounds that magnify the damage to the environment (Desmet et al., 2005; Moqadam et al., 2015). Different studies have focused on the biological degradation of plastics, reporting on the capacity of soil invertebrates to use these materials as food, observing partial or complete transformation (Bombelli et al., 2017; Yang et al., 2015a). Similarly, the ability of various microorganisms to use plastic as the sole source of carbon has been evaluated. Such is the case of Orr et al., (2004), who evaluated the degradation capacity of polyethylene by a strain of the fungus Rhodococcus ruber, observing an $8 \%$ biodegradation of this material. Likewise, Velasco et al., (1998) studied a molecular biology of Psendomonas sp. and the the enzymes involved in the transformation of styrene to phenylacetate. Similarly, Yang et al., (2015b) established that the bacterium Exiguobacterium sp. from the digestive tract of the mealworm, or Tenebrio molitor beetle larvae, has the ability to degrade PS.

In the present study, we build on the body of work on PS degradation by the gut bacteria of T. molitor larvae. We sought to test the hypothesis the that the gut bacteria of T. molitor larvae have the ability to use PS as sole source of carbon, as has been reported in other studies, however, this ability does not varies in relation to geographic location were mealworm is studied.Specifically, we evaluated the growth capacity of T. molitor and the bacteria isolated from its digestive tract in the presence of PS as the sole carbon source, to establish the role of these microbiota in the utilization of the PS and to evaluate whether this capacity is generalized for all the species, regardless of the geographic location of the organism.

\section{Materials and Methods}

\section{Environmental adaptation of the T. molitor larvae}

A total of 100 individual T. molitor larvae (14 days old) were used. Mealworms were collected in the locality of in Nilo, department of Cundinamarca (Colombia) (altitude of 336 m.a.s.l. and annual average temperature of $26.5^{\circ} \mathrm{C}$ ) and transported alive in a cardboard box covered with insulating materials to 
facilitate the mealworms acclimation to temperature and weather conditions in the city of Bogota (altitude of 2630 m.a.s.l. and annual average temperature of $14{ }^{\circ} \mathrm{C}$ ), where the experiments were carried out. Once in the laboratory, the mealworms were left to acclimate to the new environmental conditions for one week. Then, they were placed in a glass container of $13 \times 15 \times 15 \mathrm{~cm}$ $(\mathrm{H} \times \mathrm{L} \times \mathrm{W})$ with a supply of $500 \mathrm{~g}$ of wheat flour as a source of food. During this period, room temperature was recorded daily $\left(23^{\circ} \mathrm{C}-26^{\circ} \mathrm{C}\right)$ and light was kept at a minimum due to the mealworms photophobic behavior.

\section{Evaluation of PS intake}

After the acclimation week, a total of 60 T. molitor larvae were separated in groups of 15 individuals and deposited in four glass containers of 10x10x15 $\mathrm{cm}(\mathrm{H} \times \mathrm{L} \times \mathrm{W})$. The acclimation conditions, previously described, were maintained for the first group hence becoming the control group; whereas the other three groups were fed with and an expanded PS plate of 5x9x1 cm of known weight $(1.5 \mathrm{~g})$. During 4 months and on a biweekly basis, the change in mass of control and treatment larvae were recorded with an analytical balance. The mass of the PS plates in the treatment groups was likewise assessed. In parallel, one PS plate of $4 \times 7 \times 1 \mathrm{~cm}(1.0 \mathrm{~g})$ was placed in fith glass container to track the effect of the environmental conditions on the mass of the PS plate.

The mealworms that were not used in the experiments were kept until reaching their imago or adult stage, and were then used to evaluate their capacity to ingest PS as a food source. To do this, a total of 15 T. molitor adults were placed in contact with a PS plate of 5x9x1 cm (1.5 g) which was visually inspected for two weeks to find changes in its surface that were signs of ingestion by the beetles.

\section{Isolation and identification of the T. molitor gut bacteria}

After the fourth month, the digestive tracts of the T. molitor larvae, fed on PS plates, were excised under a stereoscope and sterile conditions with the help of a scalpel. The obtained digestive tract contents were subjected to serial dilutions up to $10^{-7}$, and the last three dilutions were sown on nutritive agar (agar-agar $15.0 \mathrm{~g} / 1$, beef extract $3.0 \mathrm{~g} / 1$, and gelatin peptone $5.0 \mathrm{~g} / \mathrm{l}$ ). These sowings were incubated at $\left(30^{\circ} \mathrm{C}\right)$, in the presence and absence of oxygen, to promote the growth of aerobic and anaerobic bacteria. To obtain pure cultures from each strain, multiple peals were made on a Petri dish until a single colonial morphology was observed.

Subsequently, each bacterial isolate was coded and biochemically characterized through TSI, MRVP, Citrate, Urease, Catalase, Oxidase, and motility tests as well as Gram staining. Additional isolate identification was performed with molecular barcoding via $16 \mathrm{~S}$ rRNA sequencing and subsequent comparison of 
the obtained sequences with databases such as RDP, Greengenes, and NCBI RefSeq / RNA. All bacterial isolates were tested for growth on PS (see the following section) and cryopreserved for future research. Adult T. molitor microbiota was isolated, grown, and tested following the same procedure above.

Evaluation of the growth of bacteria on PS as the sole carbon source

To evaluate the growth of mealworm gut bacteria isolates on PS, $0.1 \mathrm{ml}$ of each resuspended isolate were cultured at $30{ }^{\circ} \mathrm{C}$ for 3 weeks in plates containing minimal salt medium (KH2PO4 $0.7 \mathrm{~g} / 1, \mathrm{~K} 2 \mathrm{HPO} 40.7 \mathrm{~g} / \mathrm{l}$, MgSO4*7H2O $0.7 \mathrm{~g} / 1, \mathrm{NH} 4 \mathrm{NO} 31.0 \mathrm{~g} / \mathrm{l}, \mathrm{NaCl} 0.005 \mathrm{~g} / \mathrm{l}, \mathrm{FeSO} 4 * 7 \mathrm{H} 2 \mathrm{O}$ $\left.0.002 \mathrm{~g} / 1, \mathrm{ZnSO} 4 * 7 H 2 \mathrm{O} 0.002 \mathrm{~g} / 1, \mathrm{MnSO} * \mathrm{H}_{2} \mathrm{O} 0.001 \mathrm{~g} / \mathrm{l}\right)$, agar (15 g/l), and PS sheets. Each PS sheet was prepared from $2.3 \mathrm{~g}$ of expanded PS dissolved in a benzene solution and recovered after solvent evaporation. During these 3 weeks, the formation of colonies on the agar and PS sheet surfaces was monitored. The plates showing colonial growth were observed under a scanning electron microscope (SEM) at magnifications of $17500 X, 18000 X$, $22000 X, 26500 X, 29000 X$ and $31000 X$ to evaluate changes in the material imputable to microbial growth.

\section{Results and Discussion}

PS intake by T. molitor larvae

All glass containers with T. molitor larvae and PS plates had signs of PS consumption. The PS plates exhibited holes and tunnels, where the T. molitor larvae were found (Fig. 1A). Also, the mass of the plates decreased in the presence of the larvae (Fig. 2). In contrast, in the container without larvae, the PS plate did not reveal any changes in its morphology or weight (Fig. 1B).

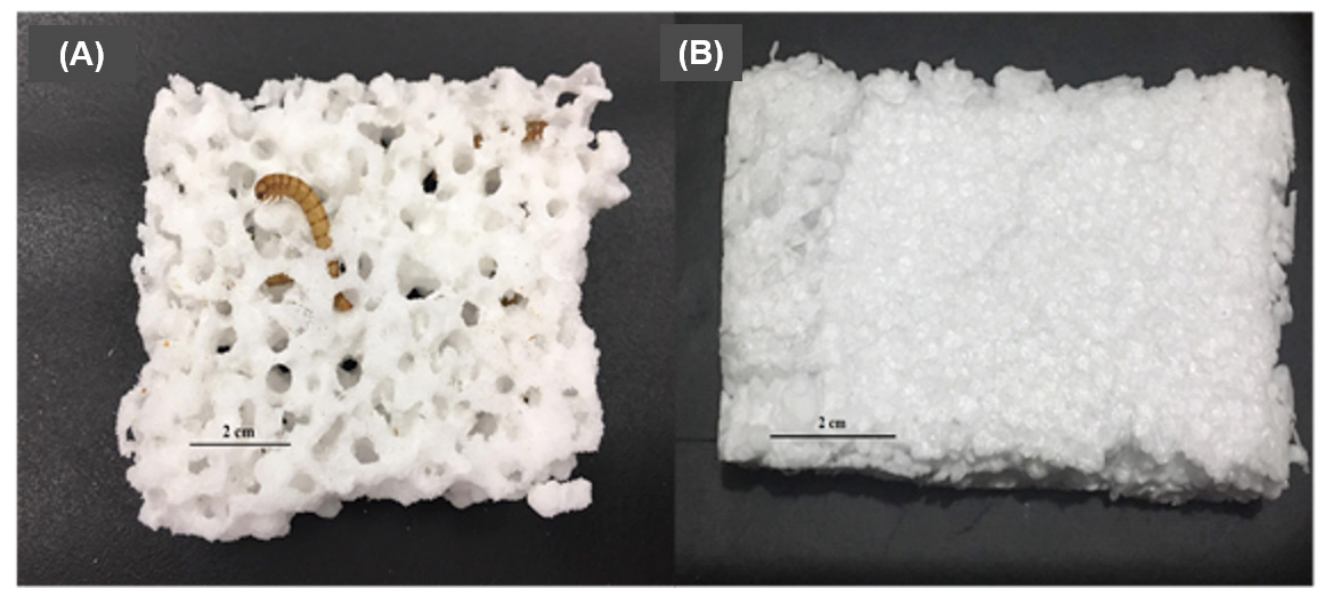

Figure 1. (A) Photograph of the mealworm (Tenebrio molitor larvae). The consumption of the polystyrene (PS) plate is evident by the holes and tunnels formed. (B) Photograph of the polystyrene plate used as a negative control. 


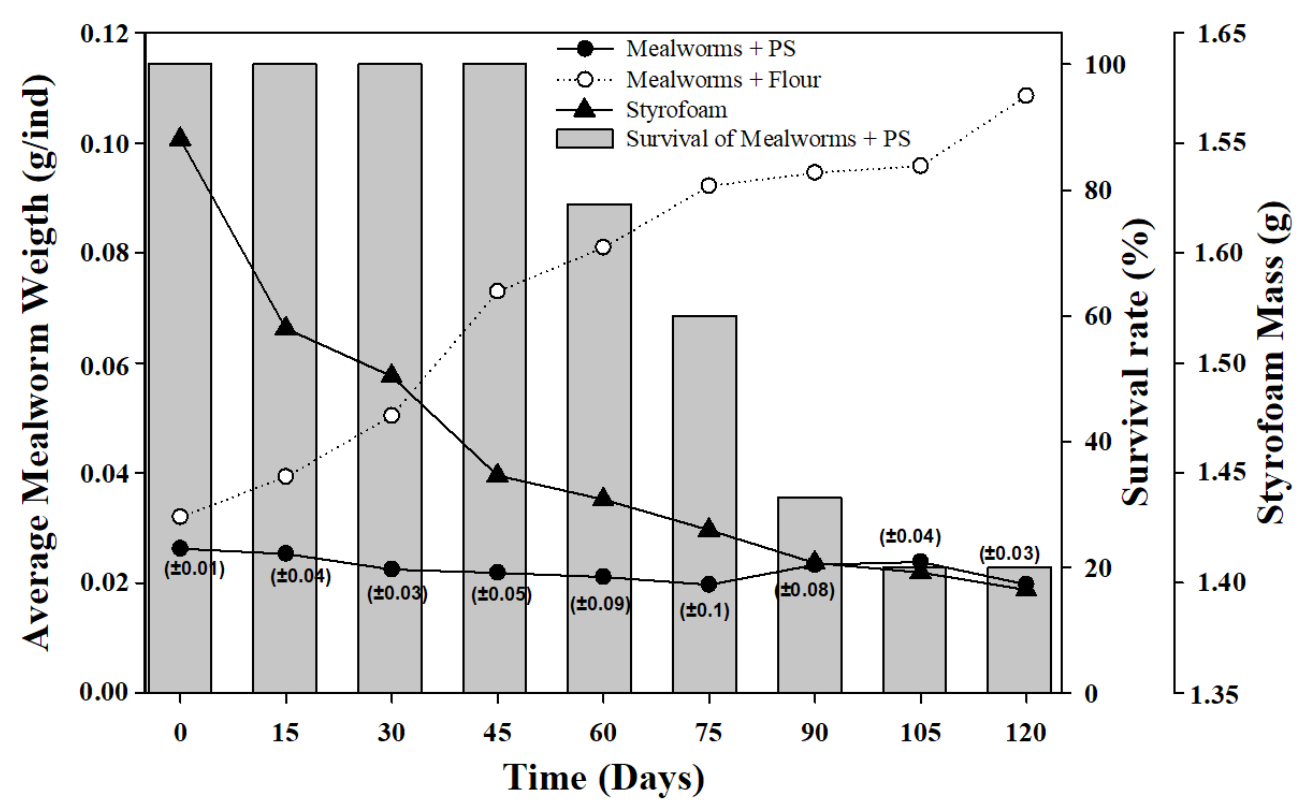

Figure 2. Relationship between average weight and survival of mealworms and polystyrene plates mass change throughout the experiment. Average biomass of a sample of 45 mealworms fed only on polystyrene (black circles) and 15 mealworms fed on wheat our (white circles), weight of the PS plates (triangles), and survival rate of the mealworms under controlled conditions over a period of 4 months (grey bars).

Mealworms fed on wheat flour steadily gained biomass throughout the experiment. Whereas those fed only on PS tended to maintain or decrease their biomass despite evidence of plate consumption (Fig. 2). Our observations indicate that T. molitor larvae were capable of consuming PS, generating distinguishable changes in the plates. However, PS was of little nutritional value to these larvae as indicated by the presence of smaller-size surviving individuals at the end of the experiment. Since PS is not composed of organic molecules, it lacks the carbohydrates and proteins, otherwise found in wheat flour, necessary for larval growth (Catalán et al., 2011).

Yang et al., (2018) observed a biomass loss in T. molitor larvae fed on PS with a survival rate of $85 \%$ after 32 days of incubation. These values are similar to those found in the present work, with a $100 \%$ survival rate observed at day 60 (Fig. 2). Allegedly, mealworms are capable of consuming PS, managing to survive for a while. Yet, PS alone does not provide the necessary energy for biomass generation because the surviving larvae lost weight and shrunk.

Furthermore, after two months of feeding only on PS, larval survival dropped by $(20 \%$ or $40 \%)$ despite having available PS plates. Survival could also have 
been affected because of cannibalism. The complete or partial disappearance of mealworm bodies is a likely sign of cannibalism. This behavior can be triggered when the relative humidity or moisture content of foods is low (Ichikawa \& Kurauchi, 2009). Since PS is a hygroscopic material, it may not help meet mealworm water needs.

T. molitor larvae have gained the attention of the scientific community due to their capacity to consume PS. However, it is not yet clear whether adults retain this capacity. In this work, T. molitor adults were allowed to feed on PS plates only, but after 15 days of incubation, none of the PS plate surfaces exhibited significant changes. The apparent inability of adults to feed on PS could be attributed to larval-to-adult jaw structure changes (Wilson, 1971), preventing adults from breaking and ingesting PS. Alternatively, changes in intestinal microbiota composition through the life stages of T. molitor (Wynants et al., 2017) may lead to the adult's inability to process and transform PS.

\section{Larval and adult T. molitor gut bacteria}

Nine morphologically different bacterial strains were isolated from T. molitor digestive tracts. Five, of these isolates, were obtained from larvae and the remaining four from adults. Each isolate received a numerical code preceded by the letters $\mathrm{G}$ (for larval origin) or $\mathrm{E}$ (for adult origin). Table 1. shows the morphological and biochemical characteristics of the nine isolates. All of the isolates had bacillary form, and five of them were Gram-negative. In general, the isolates were facultative, fermenting bacteria, with negative mobility and urease test results. Furthermore, the sequencing of their respective $16 \mathrm{~S}$ ribosomal RNA regions revealed that two of the strains from larval guts were members of the genus Bacillus, whereas the other three larval gut isolates belonged to the genus Stenotrophomonas. Similarly, two of the bacterial isolates from adult guts belonged to the genus Bacillus, and the remaining two, to the genera Pantoea and Erwinia (Table 1). The observed differences in the bacteria inhabiting the digestive tracts of larval and adult T. molitor could be related to the loss of the ability of the adult to use PS as a source of food.

Yang et al., (2015b) were the first to identify the bacteria in the digestive tract of T. molitor larvae involved in the transformation of PS. The authors obtained a total of 13 bacterial strains, chiefly Enterobacteriaceae, and determined that a member of the genus Exiguobacterium was the main responsible for the degradation of PS. In the present study, however, the most common isolates belonged to the genus Bacillus. This contrast highlights the effect of the diet on the composition of gut microbiota in insects of the same species. In the previously mentioned study, the acclimation diet of the mealworms consisted of oat flakes, whereas in the present work, it was wheat 
Table 1. Morphological and biochemical characteristics of the bacterial strains isolated from the digestive tract of Tenebrio molitor. The molecular identification is based on the sequencing of $16 \mathrm{~s} r \mathrm{RNA}$ region.

\begin{tabular}{|c|c|c|c|}
\hline $\begin{array}{l}\text { Isolated } \\
\text { Strains } \\
\text { Code }\end{array}$ & $\begin{array}{l}\text { Morphological } \\
\text { Characteristics }\end{array}$ & $\begin{array}{l}\text { Biochemical } \\
\text { Characteristics }\end{array}$ & $\begin{array}{l}\text { Molecular } \\
\text { Identication }\end{array}$ \\
\hline $1 \mathrm{G}$ & $\begin{array}{l}\text { Cells with bacillary } \\
\text { morphology that generate } \\
\text { white colonies, circular with } \\
\text { wavy edge. }\end{array}$ & $\begin{array}{l}\text { Gram-positive bacterium, } \\
\text { lactose or sucrose fermenter } \\
\text { with gas production. Positive } \\
\text { indole or catalase, with } \\
\text { motility. }\end{array}$ & Bacillus anthracis \\
\hline $3 G$ & $\begin{array}{l}\text { Cells with bacillary } \\
\text { morphology that generate } \\
\text { white colonies, punctate with } \\
\text { full edge. }\end{array}$ & $\begin{array}{l}\text { Gram-negative bacterium, } \\
\text { fermenter of the } 3 \text { sugars } \\
\text { with gas production. Positive } \\
\text { citrate and catalase with } \\
\text { motility. }\end{array}$ & $\begin{array}{c}\text { Stenotrophomonas } \\
\text { sp. }\end{array}$ \\
\hline $5 G$ & $\begin{array}{l}\text { Cells with bacillary } \\
\text { morphology that generate } \\
\text { yellow colonies, punctate } \\
\text { with full edge. }\end{array}$ & $\begin{array}{l}\text { Gram-negative bacterium, } \\
\text { fermenter of the } 3 \text { sugars } \\
\text { with gas production. Positive } \\
\text { VP and oxidase with motility. }\end{array}$ & $\begin{array}{c}\text { Stenotrophomonas } \\
\text { sp. }\end{array}$ \\
\hline $8 G$ & $\begin{array}{l}\text { Cells with bacillary } \\
\text { morphology that generate } \\
\text { white colonies, circular with } \\
\text { full edge }\end{array}$ & $\begin{array}{l}\text { Gram-positive bacterium, } \\
\text { glucose or sucrose fermenter } \\
\text { with no gas production. } \\
\text { Positive catalase and oxidase } \\
\text { with motility. }\end{array}$ & Bacillus sp. \\
\hline $10 \mathrm{G}$ & $\begin{array}{l}\text { Cells with bacillary } \\
\text { morphology that generate } \\
\text { white colonies, punctate with } \\
\text { full edge. }\end{array}$ & $\begin{array}{l}\text { Gram-negative bacterium, } \\
\text { non-glucose fermenter, } \\
\text { positive citrate and catalase } \\
\text { with motility. }\end{array}$ & $\begin{array}{c}\text { Stenotrophomonas } \\
\text { sp. }\end{array}$ \\
\hline $11 \mathrm{E}$ & $\begin{array}{l}\text { Cells with bacillary } \\
\text { morphology that generate } \\
\text { yellow colonies, punctate } \\
\text { with full edge. }\end{array}$ & $\begin{array}{l}\text { Gram-negative bacterium, } \\
\text { lactose fermenter or sucrose } \\
\text { with no gas production. } \\
\text { Positive VP, citrate and } \\
\text { catalase with motility. }\end{array}$ & $\begin{array}{c}\text { Pantoea } \\
\text { agglomerans }\end{array}$ \\
\hline $12 \mathrm{E}$ & $\begin{array}{l}\text { Cells with bacillary } \\
\text { morphology that generate } \\
\text { white colonies, circular with } \\
\text { wavy edge. }\end{array}$ & $\begin{array}{l}\text { Gram-negative bacterium, } \\
\text { lactose or sucrose fermenter } \\
\text { with no gas production, with } \\
\text { motility. }\end{array}$ & Erwinia persicina \\
\hline $13 \mathrm{E}$ & $\begin{array}{l}\text { Cells with bacillary } \\
\text { morphology that generate } \\
\text { white colonies, circular with } \\
\text { wavy edge. }\end{array}$ & $\begin{array}{l}\text { Gram-positive bacterium, } \\
\text { glucose or sucrose fermenter } \\
\text { with no gas production. } \\
\text { Positive catalase with } \\
\text { motility. }\end{array}$ & Bacillus sp. \\
\hline $14 \mathrm{E}$ & $\begin{array}{l}\text { Cells with bacillary } \\
\text { morphology that generate } \\
\text { white colonies, circular with } \\
\text { wavy edge. }\end{array}$ & $\begin{array}{l}\text { Gram-positive bacterium, } \\
\text { lactose or sucrose fermenter } \\
\text { with gas production. Positive } \\
\text { catalase with motility. }\end{array}$ & Bacilus anthracis \\
\hline
\end{tabular}


flour. Multiple works with insects have shown that feeding substrates, as well as breeding and development conditions determine the individual's gut microbiota composition (Broderick \& Lemaitre, 2012; Broderick et al., 2004; Kane \& Breznak, 1991; Santo Domingo et al., 1998; Wynants et al., 2017).

\section{Bacterial growth on PS as the sole carbon source}

Fig. 3 shows the growth of one of the isolates on PS, as the sole carbon source. The isolates formed colonies around, above, or below the PS sheets. Turbidity and darkening of the mineral medium were also signs of bacterial growth. The observed morphologies differed from those expressed by the strains isolated in nutritive agar. Isolates, revealing growth on PS sheets, were observed under a scanning electron microscope (SEM) (Fig. 4). Three of these isolates, namely

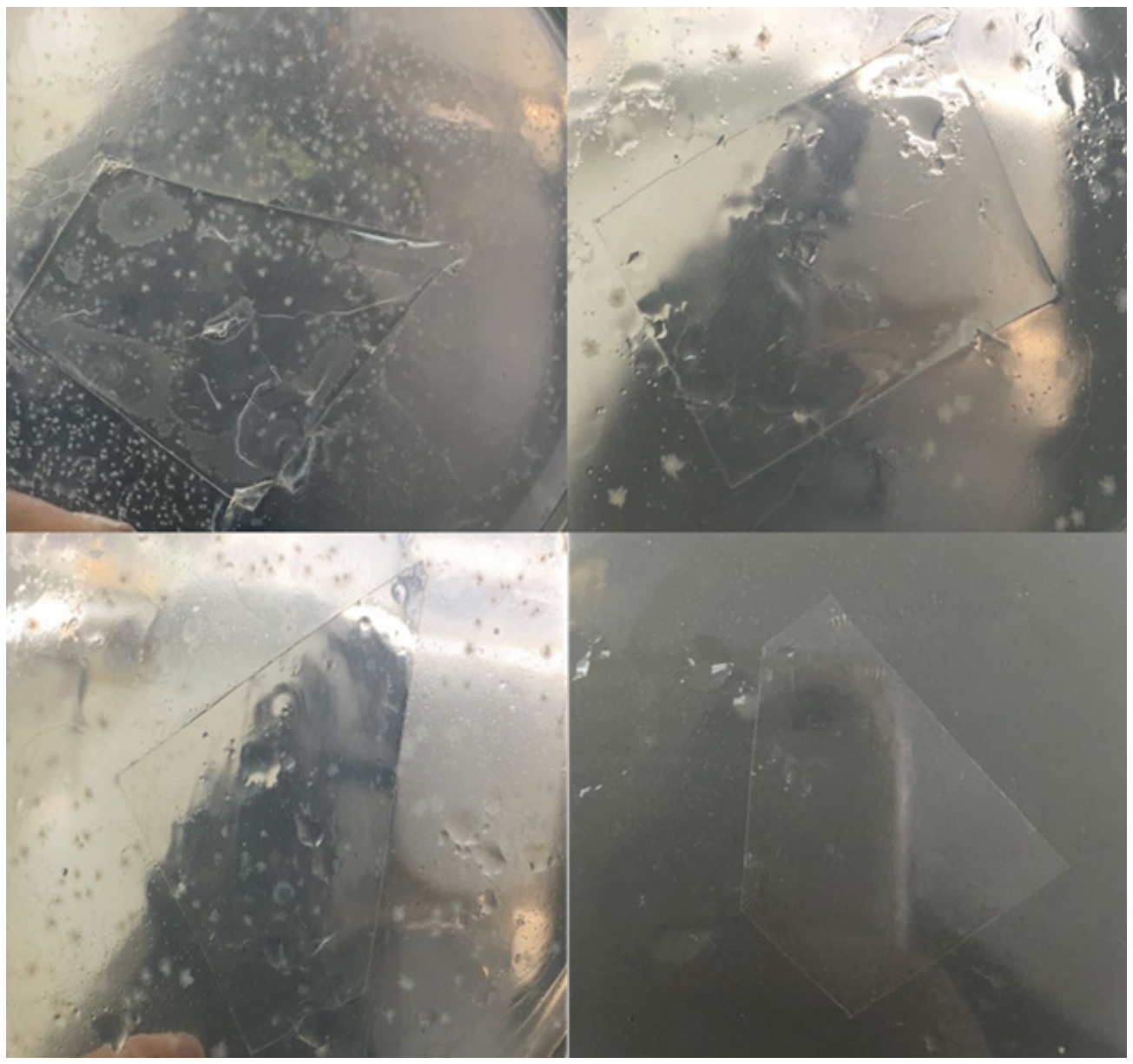

Figure 3. Photographs of colonial growth and formation of biofilm on PS sheets in minimal salt agar of some of the strains isolated from the digestive tract of Tenebrio molitor. 


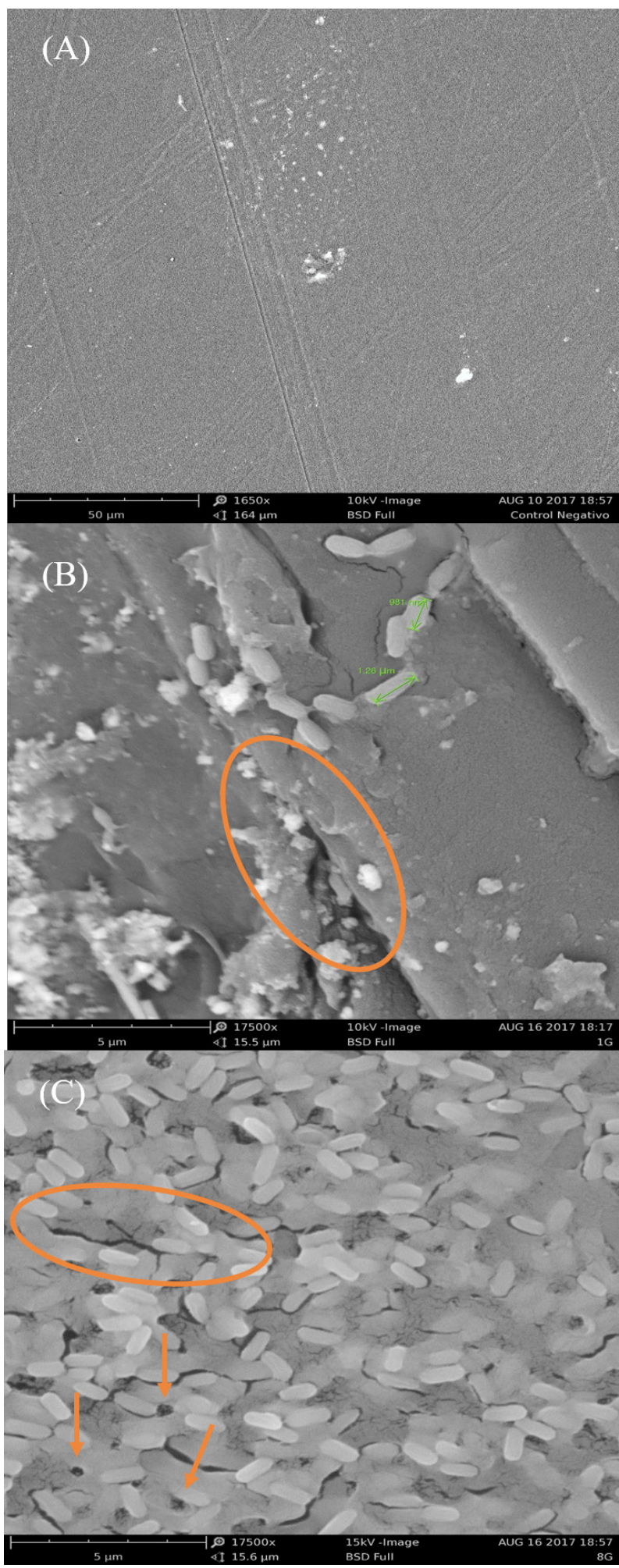

Figure 4. Microphotographs of the surface of the PS sheets after a period of 3 weeks of incubation. (A) Control sheet, without sowing of bacteria, (B) Modification of the surface of the sheet by the action of isolate $1 \mathrm{G}$ bacteria due to the proliferation of microorganisms and the appearance of furrows and holes in the material, not present in the negative control. (C) Modification of the PS sheet surface by the action of the isolate $8 \mathrm{G}$ bacteria. Grooves and holes in the observed PS sheet, absent in the negative control, evidence its consumption. 
Bacillus anthracis, Bacillus sp, and Stenotrophomonas sp. formed tunnels, cracks, and cellular aggregates on the PS sheets. None of these changes were observed in the control sample (PS sheet without microorganism). Multiple SEM-assisted works have documented bacterial-driven transformations of PS and other plastics (Ho et al., 2018; Sekhar et al., 2016; Skariyachan et al., 2016; Yang et al., 2015a; Yang et al., 2015b; Yoshida et al., 2016). These transformations start with biofilm generation, on the material's surface, followed by material deterioration because of the enzymatic activity of the microorganisms.

The metabolic pathways involved in the transformation of PS are still unclear. Nevertheless, the oxidation of styrene to phenylacetate, via the citric acid cycle, is common among different microorganisms (Ho et al., 2018). Bacteria of genus Bacillus stand out for their capacity to transform styrene to phenylacetate. Bacillus monocultures or consortia have been studied in different PS degradation experiments (Asmita et al., 2015; Atiq et al., 2010; Kiatkamjornwong et al., 1999). Our results highlight the importance of Bacillus in the degradation of PS. Taking into account that four out of nine isolates obtained from the intestinal tract of T. molitor belonged to the genus Bacillus and two of them elicited signs of PS degradation, namely forming biofilms on the material and triggering its wearing.

Finally, although PS sheet wearing was not evaluated with bacteria isolated from adult $T$. molitor digestive tracts, there is evidence that bacteria of the genus Pantoea, present in the adult gut isolates in our study, have the capacity to degradate plastics such as low-density polyethylene (Skariyachan et al., 2016). Additionally, taking into account that our T. molitor adults also have Bacillus in their intestinal flora, it is likely that T. molitor can digest PS. But, due to the structural changes in their jaws, it may not be possible for them to ingest it.

\section{Conclusions}

In light of our results, we can conclude that T. molitor larvae can use PS as food. Though, PS alone cannot meet larval nutritional needs. Larvae feeding only on PS for extended periods reduced their body size and commenced exhibiting cannibalistic behaviors. Furthermore, this use of PS by T. molitor larvae is conceivable due to the presence of bacteria in their digestive tract with the ability to grow with this polymer as their sole source of carbon. Likewise, the larval capacity seems not to reamin in adults, which could be attributed to larval-to-adult jaw changes, preventing from breaking and ingesting PS. Alternatively, changes in intestinal microbiota composition through the life stages of T. molitor may lead to the adult inability to process and trasnform PS. 


\section{References}

Acoplásticos. Plásticos en Colombia. XLV ed, Bogotá. 2017.

Asmita K, Shubhamsingh T, Tejashree S. Isolation of plastic degrading micro-organisms from soil samples collected at various locations in Mumbai, India. International Research Journal of Environmental Sciences, 4(3): 77-85, 2015.

Atiq N, Ahmed S, Ali MI, Ahmad B, Robson G. Isolation and identification of polystyrene biodegrading bacteria from soil. African Journal of Microbiology Research, 4(14): 1537-1541, 2010.

Barnes DK, Galgani F, Thompson RC, Barlaz M. Accumulation and fragmentation of plastic debris in global environments. Philosophical Transactions of the Royal Society London B: Biological Sciences, 364(1526): 1985-1998, 2009.

doi: $10.1098 /$ rstb.2008.0205

Bombelli P, Howe CJ, Bertocchini F. Polyethylene bio-degradation by caterpillars of the wax moth Galleria mellonella. Current Biology, 27(8), R292-R293. 2017.

doi: 10.1016/j.cub.2017.02.060

Božek M, Hanus-Lorenz B, Rybak J. The studies on waste biodegradation by Tenebrio molitor. E3SWeb of Conferences. EDP Sciences. pp. 00011. 2017.

doi: $10.1051 /$ e3sconf/20171700011

Broderick NA, Lemaitre B. Gut-associated microbes of Drosophila melanogaster. Gut microbes, 3(4), 307-321. 2012.

doi: 10.4161/gmic.19896

Broderick NA, Raffa KF, Goodman RM, Handelsman J. Census of the bacterial community of the gypsy moth larval midgut by using culturing and culture-independent methods. Applied and Environmental Microbiology, 70(1), 293-300. 2004.

doi: 10.1128/AEM.70.1.293-300.2004

Cardoso ECL, Oliveira RR, Machado GAF, Moura EA. Study of Flexible Films Prepared from PLA/PBAT Blend and PLA E-Beam Irradiated as Compatibilizing Agent. in: Characterization of Minerals, Metals, and Materials 2017. Springer, pp. 121-129. 2017.

doi: 10.1007/978-3-319-51382-9_14 
Catalán TP, Barceló M, Niemeyer HM, Kalergis, AM, Bozinovic F. Pathogen-and diet-dependent foraging, nutritional and immune ecology in mealworms. Evolutionary Ecology Research, 13(7), 711723. 2011.

Desmet K, Schelfaut M, Sandra P. Determination of bromophenols as dioxin precursors in combustion gases of fire retarded extruded polystyrene by sorptive sampling-capillary gas chromatographymass spectrometry. Journal of Chromatography A, 1071(1-2), 125129. 2005.

doi: 10.1016/j.chroma.2004.12.019

Ferrándiz-Mas V, García-Alcocel E. Durability of expanded polystyrene mortars. Construction and Building Materials, 46, 175182. 2013.

doi: 10.1016/j.conbuildmat.2013.04.029

Ho BT, Roberts TK, Lucas S. An overview on biodegradation of polystyrene and modified polystyrene: the microbial approach. Critical Reviews in Biotechnology, 38(2), 308-320. 2018.

doi: 10.1080/07388551.2017.1355293

Ichikawa $\mathrm{T}$ and Kurauchi T. Larval cannibalism and pupal defense against cannibalism in two species of tenebrionid beetles. Zoological science, 26(8), 525-530. 2009.

doi: $10.2108 /$ zsj.26.525

Kane MD and Breznak JA. Effect of host diet on production of organic acids and methane by cockroach gut bacteria. Applied and Environmental Microbiology, 57(9), 2628-2634. 1991.

Kiatkamjornwong S, Sonsuk M, Wittayapichet S, Prasassarakich P, Vejjanukroh PC. Degradation of styrene-g-cassava starch filled polystyrene plastics. Polymer Degradation and Stability, 66(3), 323335. 1999.

doi: 10.1016/S0141-3910(99)00082-8

Moqadam SI, Mirdrikvand M, Roozbehani B, Kharaghani A, Shishehsaz MR. Polystyrene pyrolysis using silica-alumina catalyst in fluidized bed reactor. Clean Technologies and Environmental Policy, 17(7), 1847-1860. 2015.

doi: 10.1007/s10098-015-0899-8 
Orr IG, Hadar Y, Sivan A. Colonization, biofilm formation and biodegradation of polyethylene by a strain of Rhodococcus ruber. Applied Microbiology and Biotechnology, 65(1), 97-104. 2004.

doi: 10.1007/s00253-004-1584-8

Santo Domingo JW, Kaufman MG, Klug MJ, Tiedje JM. Characterization of the cricket hindgut microbiota with fluorescently labeled rRNA-targeted oligonucleotide probes. Applied and Environmental Microbiology, 64(2), 752-755. 1998.

Sekhar VC, Nampoothiri KM, Mohan AJ, Nair NR, Bhaskar T, Pandey A. Microbial degradation of high impact polystyrene (HIPS), an e-plastic with decabromodiphenyl oxide and antimony trioxide. Journal of Hazardous Materials, 318, 347-354. 2016.

doi: 10.1016/j.jhazmat.2016.07.008

Skariyachan S, Manjunatha V, Sultana S, Jois C, Bai V, Vasist KS. Novel bacterial consortia isolated from plastic garbage processing areas demonstrated enhanced degradation for low density polyethylene. Environmental Science and Pollution Research International, 23(18), 18307-18319. 2016.

doi: 10.1007/s11356-016-7000-y

Velasco A, Alonso S, Garcia JL, Perera J, Díaz E. Genetic and functional analysis of the styrene catabolic cluster of Pseudomonas sp. Strain Y2. Journal of Bacteriology, 180(5), 1063-1071. 1998.

Wilson M. The morphology and mechanism of the pupal gin-traps of Tenebrio molitor L.(Coleoptera, Tenebrionidae). Journal of Stored Products Reserach, 7(1), 21-30. 1971.

doi: 10.1016/0022-474X(71)90034-8

Wynants E, Crauwels S, Lievens B, Luca S, Claes J, Borremans A, Bruyninckx L, Van Campenhout L. Effect of post-harvest starvation and rinsing on the microbial numbers and the bacterial community composition of mealworm larvae (Tenebrio molitor). Innovative Food Science and Emerging Technologies, 42, 8-15. 2017.

doi: 10.1016/j.ifset.2017.06.004 
Yang SS, Brandon AM, Flanagan JCA, Yang J, Ning D, Cai S Y, Fan HQ, Wang ZY, Ren J, Benbow E. Biodegradation of polystyrene wastes in yellow mealworms (larvae of Tenebrio molitor Linnaeus): Factors affecting biodegradation rates and the ability of polystyrene-fed larvae to complete their life cycle. Chemosphere, 191, 979-989. 2018.

doi: 10.1016/j.chemosphere.2017.10.117

Yang Y, Yang J, Wu WM, Zhao J, Song Y, Gao L, Yang R, Jiang L. Biodegradation and mineralization of polystyrene by plasticeating mealworms: Part 1. Chemical and physical characterization and isotopic tests. Environmental Science and Technology, 49(20), 12080-12086. 2015a.

doi: 10.1021/acs.est.5b02661

Yang Y, Yang J, Wu WM, Zhao J, Song Y, Gao L, Yang R, Jiang L. Biodegradation and mineralization of polystyrene by plastic-eating mealworms: Part 2. Role of gut microorganisms. Environmental Science Technology, 49(20), 12087-12093. 2015b.

doi: $10.1021 /$ acs.est.5b02663

Yoshida S, Hiraga K, Takehana T, Taniguchi I, Yamaji H, Maeda Y, Toyohara K, Miyamoto K, Kimura Y, Oda K. A bacterium that degrades and assimilates poly (ethylene terephthalate). Science, 351(6278), 1196-1199. 2016.

doi: $10.1126 /$ science.aad6359

Zalasiewicz J, Waters CN, do Sul J AI, Corcoran PL, Barnosky AD, Cearreta A, Edgeworth M, Galuszka A, Jeandel C, Leinfelder R. The geological cycle of plastics and their use as a stratigraphic indicator of the Anthropocene. Anthropocene, 13, 4-17. 2016.

doi: 10.1016/j.ancene.2016.01.002 


\section{Tenebrio molitor y el crecimiento de sus bacterias intestinales en presencia de poliestireno (PS) como única fuente de carbono}

Resumen: Aunque el poliestireno (PS) se considera un material no biodegradable, trabajos recientes han mostrado la capacidad de degradación de este material por medio de microorganismos, especialmente de aquellos que hacen parte de la microbiota natural del tracto digestivo de algunos invertebrados. El presente trabajo buscó evaluar el crecimiento de la larva del gusano de la harina (Tenebrio molitor) y sus bacterias, usando PS como única fuente de carbono. De esta forma fue posible demostrar el consumo de placas de PS por la larva, evidenciado en agujeros y túneles en el material. Sin embargo, el PS no es suficiente nutricionalmente para que la larva gane biomasa, por lo que se redujeron notablemente su tamaño y tiempo de supervivencia. De forma similar, las bacterias aisladas del tracto digestivo de T. molitor presentaron habilidad para generar biopelículas en láminas de PS, generando cambios (grietas, huecos, etc.) en ellas, como fue observado bajo microscopia electrónica de barrido (SEM). Esto indica el posible uso de este material como fuente de carbono para su crecimiento.

Palabras clave: escarabajo; bacterias del tracto intestinal; poliestireno, espuma de poliestireno; Tenebrio. 


\section{Tenebrio molitor e o crescimento de suas bactérias intestinais em presença de poliestireno (PS) como única fonte de carbono}

Resumo: Ainda que o poliestireno (PS) seja considerado um material no biodegradável, trabalhos recentes mostram a capacidade de degradação de este material por meio de microorganismos, especialmente daqueles que fazem parte da microbiota natural do trato digestivo de alguns invertebrados. O presente trabalho buscou avaliar o crescimento da larva do verme da farinha (Tenebrio molitor) e suas bactérias, usando PS como única fonte de carbono. De esta forma foi possível demonstrar o consumo de placas de PS pela larva, evidenciado em buracos e túneis no material. Entretanto, o PS não é suficiente nutricionalmente para que a larva ganhe biomassa, visto que se reduziram de modo notável seu tamanho e tempo de sobrevivência. De maneira similar, as bactérias isoladas do trato digestivo de T. molitor apresentaram habilidade para gerar biopelículas em laminas de PS, gerando mudanças nas mesmas (ranhuras, buracos, etc.), como foi observado por meio de microscopia eletrônica de varredura (SEM). Isso indica o possível uso de este material como fonte de carbono para seu crescimento.

Palavras-chave: besouro; bactérias do trato gastrointestinal; poliestireno; Tenebrio. 


\section{Paula M. Peña-Pascagaza}

Environmental engineer with knowledge in bioprocesses, microbiology, geographic information systems, environmental study and monitoring. Successfully develop accompaniment and advice related to environmental areas such as the development of research and guidelines, management of relevant legislation, processing before competent environmental authorities and application of software. Highly effective skills such as adaptation, recursiveness, results orientation and analytical capacity.

ORCID: 0000-0001-6856-3692

\section{Nathalia A. López-Ramírez}

Is an enthusiastic and innovative Environmental Engineer who has experience in Health, Safety and Environment (HSE) aspects. She has developed post-consumption programmes for multinational companies and has knowledge about waste management, transport and handling of chemical substances and continuous improvement process.

ORCID: 0000-0003-2250-080X

\section{Miguel A. Ballen-Segura}

Ph.D. and MSc with emphasis in fundamental and applied ecology. currently works at the School of Exact Sciences and Engineering, Sergio Arboleda University as professor and researcher, developing projects related to use of microorganisms as remediation tools and their role in high mountain aquatic systems.

ORCID: 0000-0003-4998-8278 